\title{
The Effect of Modeling Learning Strategy and Cooperative Behavior on Civic Education Learning Achievement
}

\author{
Evi Susilawati \\ Lecturer of Civic Education Study Program \\ Faculty of Teaching and Education Science, Islamic University of North Sumatera \\ Medan, Sumatera Utara, Indonesia \\ Email: evi.utnd@gmail.com
}

\begin{abstract}
The purpose of this study to see the effect of learning achievements Civic Education, cooperative behavior and the use of modeling learning strategies in students of class VII SMP Negeri I Labuhan Deli, Deli Serdang District of North Sumatra Province. The population in this study was 380 students and the sample was students. This research was quasi experiment with class VII-3 as experiment class and class VII-5 as control class. This study used descriptive method with quantitative data and analyzed by using Analysis of Variance (ANAVA). The results showed that the data of student achievement that have cooperative behavior which were taught by using modeling learning strategy, obtained the average score $(x)=23.73$, while the learning achievement of students who have cooperative behavior which were taught by using conventional learning strategy, obtained average score $(x)=18.33$. The data and the results of hypothesis testing shows that the students achievement of Civic Education who have cooperative behavior and taught by using modeling learning strategy is better than students who have cooperative behavior taught by using conventional learning strategies.
\end{abstract}

Keywords: Modeling Learning Strategy, Cooperative Behavior, and Civic Education Learning Achievement

\section{INTRODUCTION}

Nowadays, the role of teachers can not be ignored in choosing appropriate learning strategies to be applied in the learning process (Unesco.2017). Achieving a good learning objective becomes one of the indicators in a good learning process (Goss \& Sonnemann, 2017). In order for the learning objectives to be achieved, teachers are required to have teaching skills and can organize good learning materials so that learning becomes interesting. However, in the learning of education conducted in SMP Negeri 1 Deli Serdang found the existence of using learning techniques that are less mobilizing and fostering the potential of thinking, attitudes, and skills of students. Based on the results of observations that researchers do, the use of civic education techniques such as learning is caused by several factors namely, (1) learning techniques that have been institutionalized since the first and (2) learning techniques they do is the easiest technique.Learning techniques are less mobilizing and fostering the potential of thinking, attitudes, and skills of the students would certainly result in the failure of the implementation of Civic Education learning. This can be seen from the still found of $30 \%$ of students who can not complete the Criteria of Student Grade VII in the academic year 2014/2015. The low indicator of student learning outcomes is seen from non-academic aspects where many criticisms of discipline, morals and ethics, creativity, independence, and democratic attitudes, and student collaboration do not reflect the level of quality expected by the wider community. Other indicators can be seen from the low level of student cooperation behavior. Cooperation beavior is very important to be improved in students and very useful for students when they are mature (Sugiharti, Sahrani, and Tumanggor, 2017). Behavioral cooperation is often implemented in a variety of activities as it generates important benefits in the improvement of morale, the completion of specialization tasks, and the share of knowledge (Rullière, Santos, and Vialle, 2011). Cooperative behavior is always to be a very important factor in how students interact with others, giving direct criticism of students 'attitudes in relationships with other students, and provides an indication of the students self-characteristics that they need to modify in order to develop in various ways (Gong and Sanfey, 2017). Behavior of cooperation as the main foundation of mutual cooperation values that prevailed in Indonesia today has faded (Sumardjoko, 2013). In Indonesian society, slowly but surely cooperative behavior has begun to fade in most of the economic, socio-cultural and political life of Indonesian society. More ironically, parents, politicians and even the broader community provide inappropriate examples of behaviors that are contrary to these cooperative behaviors such as: (1) the increasing of desire for power and neglectful material to cooperate, (2) the nature of individualism, the existence of conflict and mutual harm, (3) the moral consensus that becomes the basic framework of social interaction based on the values of cooperation that are important enough in producing the order of life, tends to be ignored and ruled out, (4) mutual cooperation as an implementation of a form of cooperation that serves only as a mere symbol because it is often discussed but less practiced in learning activities (Efendi, 2013).Obviously this situation becomes a problem for teachers of Civic Education because the effort to form the ethics and 
moral values of students is not an easy thing to do (Wathoni, 2014). Then, the era of globalization becomes a challenge that is not less important for teachers of Civic Education. The presence of globalization led to the development of communication technology flows so rapidly, especially the mass media. These tools of communication every day introduce the values of liberalism, communism, and secularism that are contrary to the values of Pancasila and the 1945 Act which guides the behavior, ethics, morals and norms of the Indonesian nation. More ironically, these values are different from the kind of manners instilled in schools and in Indonesian society. Finally, many teachers become apathetic and frustrated in instilling the moral values embodied in the subject of Civic Education because the moral values outside the school are not applied by the students. Therefore, the researcher is interested in conducting research on learning strategy of modeling and cooperative behavior toward the learning outcomes of Civic Education. By learning to use modeling, students will learn from observing the results of the behavior of others and the behavioral results of those observations reflect an attitude imitated by students (Winkel, 2007).

\section{LITERATURE REVIEW}

\section{A.Modeling Learning Strategy}

Learning strategy is defined as planning that contains a series of activities designed to achieve certain learning objectives (Kemp, 1995). Sagala (2014) argues that learning strategy is a conceptual framework that is able to describe and write a systematic procedure in organizing learning and learning experiences to achieve certain learning goals, and serves as a guide for teachers in carrying out learning activities. Based on the understanding of the learning strategy, it can be interpreted that the learning strategy contains about predetermined learning objectives, systematic procedures using media, methods, and other equipment so as to form the learning experience of students. Thus, in determining the learning strategy, student characteristics, such as behavior, ability, cognitive function, motivation, emotion, learning strategy, and other demographic variables become significant factors in determining learning strategy (Kalati, 2016). Good learning is based on the design of instructional strategies on good instructional principles (Khuana \& Khuana, 2017). Implementation of a good learning strategy should consider the characteristics of students. Learning modeling strategy is a learning strategy that takes into account the characteristics of students and is able to grow student cooperation. By learning through modeling, students can observe models in small groups and they help each other and provide modeling in the learning process. The use of modeling learning strategy is very effective in terms of: (1) Providing experience of success (mastery experiences). Through modeling learning strategies students will observe the behavior of the model and will learn to overcome barriers in learning to become a tough student in learning. (2) Gain experience learning from the experience of others. Experience of success of others who have similarities with the experience of students in doing a learning task will usually improve the ability of students in doing the same task.
Student learning experience through modeling learning strategy is obtained through social model that usually occurs in students who lack knowledge of their own ability so as to encourage students to make observations of the model. (3) Establish students' social persuasion skills. Persuasion is the communication used to influence and persuade others. Learning by using modeling learning strategies will shape students' ability to have high social persuasion. Through this social persuasion every student will try to influence the beliefs and expectations of others. Information about influential model skills delivered verbally will give students confidence that they are actually capable of performing a task like the model does. In this strategy, there are four models that become the reference of students in learning are: (1) life model includes family members, peers, and others who have direct relationship with students; (2) the symbol model is the embodiment of behavior in the picture; (3) the verbal model is a non-behavioral model but a form of instruction such as a series of teacher instructions to the student to assemble an apparatus in a learning activity (Bandura, 1999). All three types of models should be able to attract students' attention. The model traits that can attract students' attention are: the model describes credible behavior, matches the student's behavior, provides a standard for student ideals, and provides a realistic reference as a student's behavioral comparison (Devi et al 2017). Learnt by using learning strategy consists of four processes that can be seen in Figure 1 below:

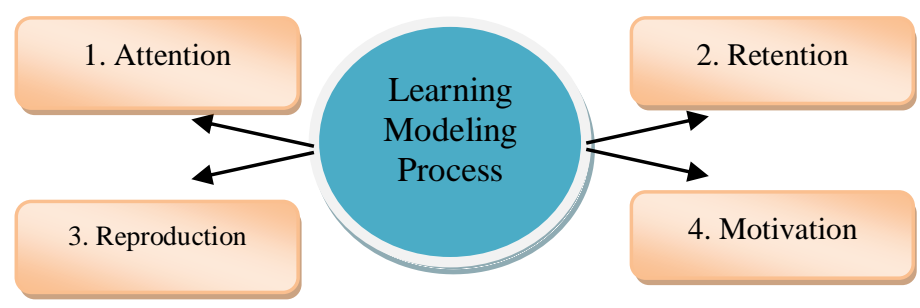

Fig. 1. Learning Process by Using Modeling Learning Strategy

The learning process using modeling learning strategy in Figure 1. is described below: (1) attention process, that is cognitive processing process by giving attention to a model where the students pay attention to interesting models, so that succeed to generate student's interest and popularity; (2) the retention process, in example the process by which the student takes notice, stores the cognitive symbols of the model's appearance in long-term memory; (3) the process of reproduction, is a process of actual appearance counseling where the behavior imitated is a change to the new behavior and not a change of physical ability; (4) reinforcement and motivation process, is the recognition of the student's response from the model of the new behavior and ultimately raises the motivation in the student to perform the new behavior.

\section{B. Cooperative Behavior}

Cooperative behavior is defined as a behavior that shows cooperation, does not contradict an individual's attitude or certain groups. Basically there are several factors that cause 
students to behave cooperatively. As for these factors according to Sears, Freedman, and Peplau (2014) as follows: (1) students will behave cooperatively when reward structures are mixed and multiply; (2) personal and situational, personal and social factors are associated with values that are in an environment where those from rural areas are usually more cooperative; (3) communication between group members, diaman more communication done within the group, the greater the occurrence of a cooperative relationship; (4) group size, when large group sizes show good cooperative behavior; (5) reciprocal relationship, this relationship is a factor behind the co-operative behavior in the group, where the previously developed cooperative behavior followed by the development of the next cooperative behavior will form a firm relationship within the group.Cooperative behavior can be developed by teachers in a classroom learning environment. The cooperative behaviors developed in learning generate positive dependence such as: goal interdependence, task interdependence, interdependence of learning resources, role interdependence, and gift interdependence (Jhonson \& Jhonson, 2017) Thus, the positive influence of cooperative behavior in learning is : (1) improving learning achievement; (2) increase retention; (3) more can be used to achieve a high level of reasoning; (4) can further encourage the growth of intrinsic motivation; (5) better suited to promote heterogeneous human-to-human relationships; (6) improving children's positive attitude toward school; (7) improving the child's positive attitude toward the teacher; (8) increase the child's self-esteem; (9) improving positive social adjustment behavior; And (10) improving life skills (Pandya, 2017).

\section{Civic Education Learning Achievement}

Learning is defined as a change in the likelihood or probability of a response that can be seen as a behavior whereby one learns the response looks better, but when one does not learn the response seems to decrease. The changes will also appear in Civic Education lessons.Civic Education is an effort of a society or government to ensure the survival of their citizens and for future generations, significantly and be able to anticipate their future, always in the context of culture, nation, state, and international relations based on the values of Pancasila and the Law The 1945 Constitution (Rahman, 2017). The educational goals Civic produces students with attitudes and behaviors: (1) faithful and cautious to God the Almighty; (2) a civilized humanity; (3) supporting national unity; (4) support people who prioritize common interests above the interests of individuals and groups; (5) support efforts to bring about a social justice in society, and (6) obey the rules and legislation (Kaelan, 2017). Through Civic education, students as citizens of the Republic of Indonesia is expected to understand, analyze, and address the problems faced by the community in \& Sustainable nation of flower and consistent with the ideals and the national goals in the opening of UUD 1945. Based on the explanation above, it can be interpreted that the subject of Civic Education has an important role in the formation of understanding, personality, and behavioral changes related to the ethics and morals of the nation.
Behavior change is seen from the learning. Learning achievement are seen from the behavioral changes in students that can be observed and measured in the form of changes in knowledge, attitudes, and skills (Korpershoek et al, 2014). Learning achievement can also be seen from the mastery of a number of knowledge and a number of new skills and new attitudes or strengthening something that has been mastered before, including understanding and mastery of learning (Denniston et al., 2017). Referring to the description of the learning achievement of Civic Education, it can be concluded that what is meant by the learning achievement of Civic Education in this study is the students' mastery of the subjects of Civic Education either the mastery of Pancasila morals or civic knowledge embodied in the form of test results test score. Tests The results of learning in this study is the learning achievement obtained by students who are limited to cognitive aspects with indicators in the form of ability in memory, understanding, and application as measured through the test results of Civic Education.

\section{RESEARCH METHODS}

This research was conducted on 380 students of SMP N 1 Labuhan Deli, Deli Serdang Regency of North Sumatera Province as experimental class VII-3 were 39 students and as control class and class VII-5 were 39 students. Thus, the total sample in this study was 78 students. Before the experimental activity was conducted, the samples obtained were first given a questionnaire of cooperative behavior to know the characteristics of student's kopertaf behavior. Furthermore, class VII-3 is given the modeling learning strategy and the VII5 class still using the usual learning strategy by the Civic Education teacher. The procedure for treatment treatment in the experimental class using modeling learning strategy is seen in Figure 2. below:

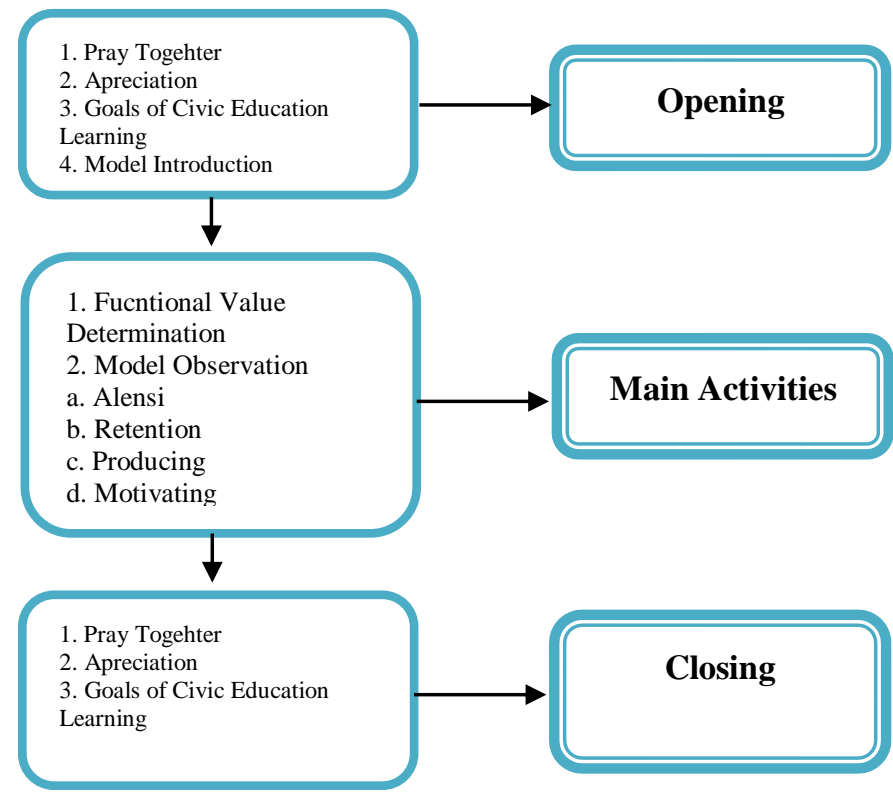

Fig. 2. Implementation Procedures of Learning Modeling Strategy Models 
At the time of the conduct of the treatments, control of internal validity is obtained so that the results obtained are actually the result of treatment given to each group of exprimenmen. This internal validity control includes: (1) historical influence. Controlled by preventing the occurrence of special events that are not due to the treatment of the exprient by way of treatment in a relatively short period of time; (2) The effect of maturity (naturation effect), controlled by giving treatment in a relatively short time, so that students not to experience physical or mental changes that may affect the learning achievement, (3) The effect of loss of participants of expenditure (mortality effects), controlled by That no student is absent during the study, (4) The effect of the instrument (instrument effect), controlled by giving the test that is the initial test and the final test; (5) The influence of statistical regression, controlled by subject is selected not based on extreme scores and tightened administration or implementation of research instruments; (6) The effect of maturity selection interactions, controlled by means of research carried out naturally. Subjects are believed to have relatively the same age and cultivated research time is relatively short. Then, control of the external validity of the study design, including: (1) Treatment selection interactions, controlled by sampling by population and randomly assigned; (2) Specifity of variable, controlled by means of all variables can be defined specifically; (3) Multi-treatment interventions, controlled in the manner it is believed that the ongoing treatment is one treatment, (5) Contamination and expriation bias, controlled by means of research does not affect the behavior of the subject. There is no bias between classes, the treatment is done in two classes, with two teachers who have the same ability and adjusted with their respective timetable.

\section{RESUlt AND DISCUSSION}

Based on the results of testing data obtained from the field obtained data on student learning achievement that have cooperative behavior taught by modeling learning strategy, obtained the average score $(\mathrm{x})=23.73$; Variance $(\mathrm{s} 2)=3.02$ And standard deviation $(\mathrm{sd})=1.75$ The highest score obtained is 26 and the lowest score is 19 . While Modus $(\mathrm{Mo})=23.5$ and Median $(\mathrm{Me})=23.67$. The following is presented Figure 3 frequency distribution of learning outcomes Civic Education students who have cooperative behaviors are taught with modeling learning strategies.

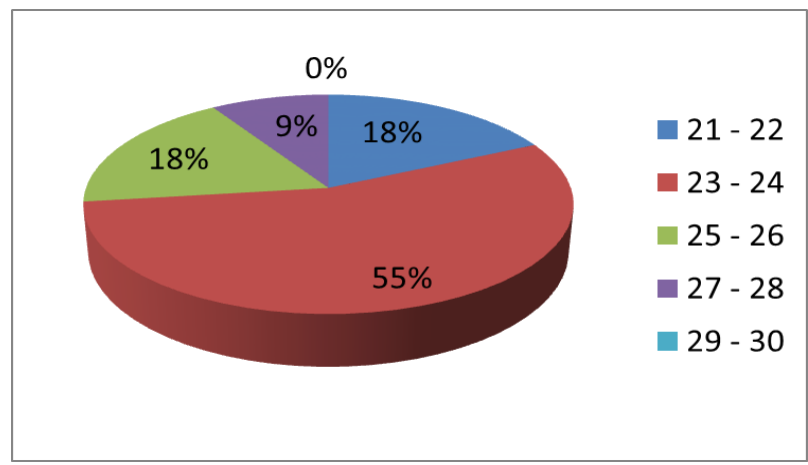

Fig. 3. Frequency Distribution of Learning Achievement Results of Citizenship Education Students Who Have Cooperative Behavior And Taught By Using Modeling Learning Strategy

Furthermore, student learning achievement that have cooperative behavior were taught by using conventional learning strategy, obtained average score $(\mathrm{x})=18,33$; Variance $(\mathrm{s} 2)=4.97$; And standard deviation $(\mathrm{sd})=2.29$. The highest score obtained was 23 and the lowest score was 15 . While Modus $(\mathrm{Mo})=19.75$ and Median $(\mathrm{Me})=19.83$. The following is presented Figure 3 frequency distribution of learning outcomes Civic Education students who have cooperative behaviors are taught with conventional learning strategies.

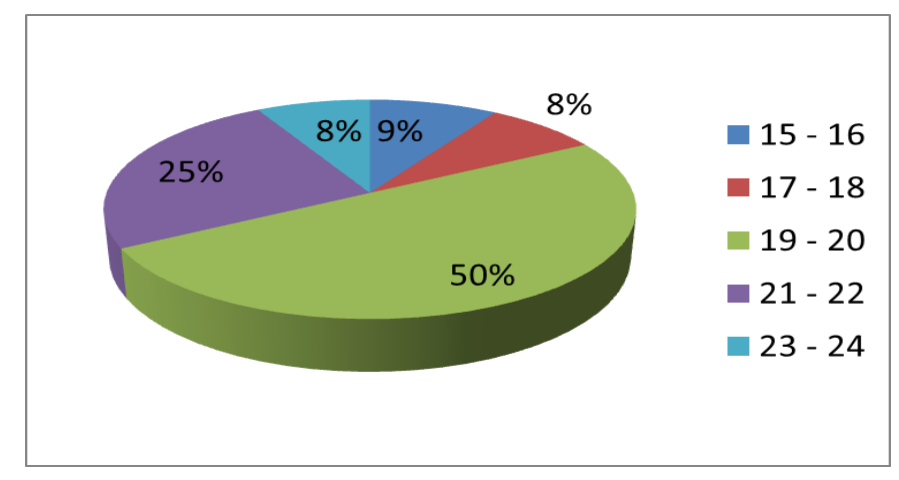

Fig. 4. Frequency Distribution of Learning Outcomes Results of Citizenship Education Students Who Have Cooperative Behavior And Taught By Using Conventional Learning Strategy

Looking at the results obtained in the field it was found that, groups of students with cooperative behaviors who were taught with modeling learning strategies received significantly higher mean scores than the group of students taught with conventional learning strategies. This is quite reasonable because the implementation of learning by using the strategy of learning modeling emphasizes the influence of the model with the learning process progresses gradually from simple to complex skills so easy to identify talents, interest, and student skills. In order for the learning process to take place gradually from the simple to the complex skills required cooperative behavior and communication.

The more communication will result in more cooperation. Communication enables students in groups to urge cooperation, discuss plans, make promises, convince each other that they are trustworthy, and understand each other. In the process of mutual understanding is the process of learning using modeling learning strategies can be implemented effectively. The findings of this research are match with Minet's research (2015) which states that developing cooperative behavior in learning modeling contributes to: (1) improving students' ability in solving various problems, (2) fostering critical thinking of students, (3) enhancing cooperation, the ability of students to interact socially with friends and the surrounding environment, (4) develop communication skills, (5) improve decency behavior, and respect differences. The study also supports the opinion of Gillies (2016) who suggests that (1) students with cooperative behaviors are more effective in achieving academic achievement, (2) cooperatively cooperative 
students have positive dependence on positive achievement and positive motivation such as students are interrelated to achieve shared learning objectives, (3) cooperative behavior can enlarge social support, enrich self-esteem, and foster psychological comfort in which these benefits are most likely to occur if the individual realizes that useful structures are cooperative structures and when individual performance accountable to the group; (4) the cooperative group is very likely to succeed if the group members of the group are interacting face-to-face and when the individual is trained in the social skills needed to cooperate effectively.

\section{ACKNOWLEDGMENT}

Author's deepest thanks to: (1) Mr. Rector of the Islamic University of North Sumatra, along with his staff, (2) Dean of Faculty of Education and Education of Islamic University of North Sumatra, May God Almighty provide health, well-being and repaying their good deeds.

\section{REFERENCES}

[1] Bandura, A. A Social Cognitive Theory of Personality. In L. Pervin \& O. John.1999.

[2] Denniston, Charlotte. Molloy, Elizabeth. Nestel, Debra. Woodward-Kron, Keating, Jennifer L. "Learning Outcomes for Communication Skills Across the Health Professions: A Systematic Literature Review and Qualitative Synthesis".Group BMJ.com:http://bmjopen.bmj.com. August.3.2017.

[3] Devi,Barkha.Khandelwal,Bidita $\&$ Das,Mridula."Application of Bandura's Social Cognitive Theory in the Technology enhanced, Blended LearningEnvironment." International Journal of Applied Research. Volume 3(1).2017.

[4] Efendi, Tajuddin Noer,"Budaya Gotong Royong Masyarakat Dalam Perubahan Sosial Saat Ini," Jurnal Pemikiran Sosiologi, Vol 2, No.1, 2013.

[5] Gillies, Robyn. M, "Cooperative Learning: Review of Research and Practice". Australian Journal of Teacher Education, Vol.41,3, March 2016.

[6] Goss. Peter, \& Sonnemann.Jolie, Engaging Students creating Classrooms That Improve Learning, Meilborne: Graftan Institute, 2017.

[7] Guong, $\mathrm{Xu}$ and Safenty, "Social Rank And Social Cooperation: Impact of Social Comparison Prosesses On Cooperative Decision Making". Journal Plos One.Chemical Biology Research, Vol.12 (4), 2017.

[8] Handbook of personality. New York, Guildford Publications: 154-196. Psychological review 106(4), 676.

[9] Jhonson, David W \& Jhonson, Roger T."The Use of Cooperative Procedures in Teacher Education and Proffesional Development".Journal for Education Teaching. Interantional research and Pedagogy. Volume 43.2017.
[10] Kalati. Amirbakzadeh Ezat, "Learning Strategies in Second Language Acquisition", Research \& Reviews: Journal of Educational Studies,Volume 2. Issue 4. December, 2016.

[11] Kaelan, H. (2017). Pendidikan Pancasila. Yogyakarta : Paradigma.

[12] Kemp. Jerrold E, Instruction Desigen: A Plan for Unit and Course Development, Belmon: Feron.1995.

[13] Khuana. Kwanchai, \& Khuana.Tanthip , “ Impressive Learning Strategies with Indoctrinating Research-Based to Craetive Thinking Skills for Educational Students", European Journal of Education Studies.Volume 3, Issue 2, 2017.

[14] Korpershoek, H., Harms, T., de Boer, H., van Kuijk, M., \& Doolaard, S. Effective Classroom Management Strategies and Classroom Management Programs for Educational Practice, Groningen: University of Groningen, 2014.

[15] Minet,Rachel Charlotte," A Qualitative Study Investigating The Sources of Teacher Efficasy Beliefs."Disertasi, Britain: University of East Angelia, 2015.

[16] Pandya. Shefali,"Interaction Effect of Co-operative Learning Model and Student's Implicit Theory of Intelligence on Students' Implicit Theory of Intelligence on Student Engagement in Mathematics".Asia Pacific Journal of Contemporary Education and Communication Technology (APJCECT) ISBN: 97809943656 82; ISSN: 2205-6181, Volume: 3, 2017.

[17] Rahman.Abd,Pendidikan Kewarganegaraan di Perguruan Tinggi, Jakarta: Celebes Media Perkasa, 2017.

[18] Rullière, J.L., Santos-Pinto, L., \& Vialle," Self-confidence and teamwork: An experimental test,"Journal Research Gate 2011-26. http://halshs.archives-ouvertes.fr/halshs00632091. 2011.

[19] Rohman.Abdul, "Pembiasaan Sebagai Basis Penanaman Nilai-Nilai Ahlak Remaja," Nadwa| Jurnal Pendidikan Islam Vol. 6, Nomor April.2012.portalgaruda.org/article. 2012.

[20] Sagala.Saiful, Konsep dan Makna Pembelajaran, Bandung: Alfabeta, 2014.

[21] Sears, D. Fredman. L.J. dan Peplau, A.L. (2014).Social Psychology.12th Edition.Los Angles: Pearson.

[22] Sumardjoko.Bambang, "Revitalisasi Nilai-Nilai Pancasila Melalui Pembelajaran PKn Berbasis Kearifan Lokal Untuk Penguatan dan jati diri bangsa," Jurnal Varia Pendidikan, Vol. 25. No. 2, Desember 2013. portalgaruda. org/article.2013.

[23] Sugiharti Tina, Riana Sahrani, Raja Oloan Tumanggor, "Evaluasi Program Community-Based Learning Evaluasi Program Community-Based Learning yang Berdampak pada Perilaku Kerjasama Siswa SMP X Depok.” Jurnal Reseach Gate, https://www.researchgate. 2017.

[24] Unesco, Education for Sustainable Develompent Goals Learning Objectives, Education Sector: United Nations Educational Scientific and Cultural Organization, 2017.

[25] Wathoni.Kharisul, "Internalisasi Pendidikan Karakter di Perguruan Tinggi: Studi Kasus di STAIN Ponorogo," Didaktika Religia Volume 2 ,No. 1 Tahun 2014. Ponorogo: Program Studi Pendidikan Agama Islam Jurusan Tarbiyah STAIN Ponorogo. portalgaruda.org/article.2014.

[26] Winkel. WS, Psikologi Pengajaran, Jakarta: PT.Gramedia Widia Sarana Indonesia,2007. 